\title{
Central Bank Digital Currencies (CBDCs) in Africa: Why CBDCs Could be A 'Disaster' for the Continent
}

\author{
Nantogmah Danaa* \\ Faculty of Finance and Accounting, University of Professional Studies, Accra \\ Sampson Vivian Esumamba \\ Faculty of Finance and Accounting, University of Professional Studies, Accra \\ Odoom Alexander Abeiku \\ Software Engineer, EYO Solutions Ltd \\ P.O box MC 1577, Takoradi, Ghana
}

\begin{abstract}
Central bank digital currencies (CBDCs) are been designed a 'new normal' for the world of finance in which payments (digital currency) can be made directly from one party to another without financial intermediaries regardless macroeconomic links. Digital currency has ushered the world of finance into uncharted waters as central banks and international institutions crumble to fine their feet's in a fast moving stream of decentralised finance (DeFi) and global stablecoins. As central banks embark on the CBDCs journey, there are number of questions which must be address: What problems are CBDC's expected to solve? How do current design thinking resolve these problems in Africa? Are there alternatives to CBDCs in Africa? Broadly, CBDCs are expected to resolve inefficient and costly domestic and cross-border payments and settlement, ensure price stability and financial stability, retain monetary policy independence and digital de-dollarization. A qualitative descriptive design has been adopted in this study.Findings. Central bank digital currencies (CBDCs) welldesigned in a new multilateral fair and just international monetary architecture has the potential to ensure price stability and financial stability in both advanced and developing economies in general, but more importantly would enable developing countries to regain some among of monetary policy independence. However, under the CBDCs design thinking within the framework of existing international monetary and financial architecture, no economy in Africa can withstand the powers of BigFintech, DeFi, global stablecoins and foreign sovereign digital currencies. This paper concludes that African countries must decide whether to cede their sovereign power to an independent monetary authority with single digital currency to manage under their control or cede their economic and financial destiny to unaccountable foreign BigFintech and/or foreign sovereign CBDCs in form of digital dollarization.
\end{abstract}

Keywords: digital currency, CBDCs, digital dollarization, international monetary system, Africa

DOI: $10.7176 /$ RJFA/12-18-03

Publication date:September $30^{\text {th }} 2021$

\section{Introduction}

After more than a decade of skepticism, economies around the world are faced with the irreversibility of digital currencies and their impact on national economies and the international monetary system has come into focus. Since Satoshi Nakamoto launched Bitcoin in 2008, private digital currencies (bitcoin, ether, litecoin, dogecoin, stellar, ripple, libiecoin, etc.) have witnessed an exponential growth from only one in 2008 to over six thousand five hundred and seventy $(6,570)$ cryptocurrencies with varied technologies and design objectives. Table 1 below show the top six digital currencies by market capitalization.

Global finance is entering uncharted waters as the rush to issue central bank digital currencies are underway. Having slept on their job, central banks across the world are engaged in catching up with a 'new normal' freely movable money in a digital era. While digital currency is expected to impact monetary and financial stability policies of all nations, its impact on least developed countries (LDCs) and some emerging economies might be devastating with potential digital dollarization, increased volatility and instability of national digital currencies. Current thinking among central banks in Africa is the rush to the issuance of central bank digital currencies (CBDCs) as a response to the increasing spread and adoption of digital currencies. This paper seeks to address these interrelated questions: (i) what problems are CBDC's expected to solve? (i) How do current design thinking resolve these problems in Africa? (iii) Are there alternatives to CBDCs in Africa?

Methodology. In this study, the methodology used is qualitative descriptive design refer to sets of research techniques used to analyse textual data and elucidate theme. The object of this research is central bank digital currencies. Secondary data obtained from articles, working papers, websites, books, reports, speeches, policy documents and legislations, and public statement/press releases. Content analysis was used as data collection tool, while thematic analysis was used as a data analysis strategy. The research process includes the following 
steps: material collection and evaluation, coding and examining meaning, and descriptive analysis of the phenomenon through the creation of themes.

\section{Review of Literature}

Despite its checkered modern history, the international monetary system has always been organised around an anchor. Since the Gold Standard era, anchors has taken notably two forms: 'a commodity or fiat currency'. In a conventional monetary system, any payment instrument is ultimately linked to a fixed amount of the anchor. That said, the relationship between the international monetary system and the monetary policy of the country issuer or manages the anchor which serves as international reserve asset has been a subject to intense research (Bordo, 1993, 2017; Eichengreen, 1993; Karczmarczyk, 2010; Chatham House, 2012). For instance, as early as the 1960s a Belgian-born economist Robert Triffin admonished that the use of one national currency to manage the world liquidity was likely to lead to a conflict between short-term domestic and long-term international objectives, he concluded that as and when these conflict ensue, national interests will trend to prevail (Bordo. 1993).

Yet in an increasingly connected and integrated global economy two camps have emerged in the international monetary system. One camp comprising major currencies that float freely and permit the free flow of capital, while the other camp consisting of 'privileged' currencies has varying degrees of control over exchange rates and cross-border flows. It is in this context that the IMF described it as something of a "nonsystem"" (Chatham House, 2012).

\subsection{International monetary system}

In modern era, the evolution of the international monetary system may be categorized into three broad epochs: gold standard (1870 - 1914) and the gold exchange standard of the inter-war years, Bretton Woods era (1946 1958; 1958 -1971) and United States dollar hegemony (1973 - date) (see Bordo, 1993). A detail discussion of the various epochs is outside the scope of this paper (see Bordo, 2017, 1993, Eichengreen, 1993, 2010; Karczmarczyk, 2010, Chatham House, 2012), however, suffice to outline some of the key issue underpinning different period. The origin of the international monetary system may be trace to the use of gold as anchor (Gold Standard) in the monetary system of the Great Britain dating back to 1717 , but the establishment of classical Gold Standard began in and around 1870.

During Great Depression, the British government suspended the Gold Standard in 1931 and by the end of the 1930s, the gold standard era came to an end paving way the for a new international monetary system culminated in the Bretton Woods arrangements with the creation of two institutions: International Monetary Fund and the World Bank in the early 1940s. These two institutions were established to help build a framework for economic cooperation designed to avoid a repetition of vicious cycle of devaluations in the 1930s (Bordo, 1993, Bordo, 2017, Chatham House, 2012). At the inception of the Bretton Woods system in July 1944, by design made the US dollar the de facto anchor ${ }^{1}$ for the international monetary system (Bordo, 2017).

Arguably, the Bretton Woods system underpinned the post-war boom in the 1950s and 1960s, yet with the United States dollar pegged to gold, tension emerged within the international monetary system as the United States began running up persistently large external deficits while supplying the global liquidity required for international transactions. In the process, the volume of dollars held as foreign reserves by both official and private holders came to exceed the amount of gold held in Federal Reserves by significant amount by 1971 (Bordo, 1993). In view of the inability of United States absorb the pressure maintaining a fixed price of gold on demand, for all those holding US dollars, President Richard Nixon decided to suspend the gold convertibility of dollars (Bretton Woods II: 1958 - 1971), effectively closing the gold window and triggering a devaluation of the US dollar and by March 1973 (Bordo, 2017).

Some scholars (Karczmarczyk, 2010) suggest the era of the Bretton Woods regime may have come to a close in 1971. Yet Bordo (1993, p.99) aver that the Bretton Woods system is still alive when define in the context of a broader purpose; "an exchange rate system that support open trade and the financing of imbalances rather than narrowly defined system of fixed exchange rates and current account convertibility".

In this context, the search for a new international monetary system lasted for another five years before a formal role of gold was removed by an amendment to the IMF Articles of Agreements which ushered in the SDRs with the United States dollar as the de facto anchor of International monetary system (see Bordo, 1993, Bordo, 2017, Chatham House, 2012). In other words, the collapse of the Bretton Woods fixed exchange rate regime between 1971 and 1973 led to the general adoption by advanced countries of a managed floating exchanges rate system (Bordo, 1993). But after nearly four decades, there is now a considerable interest both

\footnotetext{
${ }^{1}$ Pegging to the US dollar was de facto. Formally, according to Article IV of the original Articles of Agreement, parties were to be defined in terms of gold or in terms of the US dollar 'of weight and fineness of July 1, 1944', i.e. gold. So gold was intended to remain the ultimate unit of account for exchange rates. Countries in the Commonwealth mainly pegged to sterling, which was itself pegged to the dollar (Schenk, 2010; cited in Chatham House, 2012)
} 
within the IFM and the World Bank as well as within the international policy community of the need to reform what the IMF described as something of a 'non-system':

"The current non-system has the inherent weakness of a set-up with a dominant country-issued reserve currency, wherein the reserve issuer runs fiscal and external deficits to meet growing world demand for reserve assets and where there is no ready mechanism forcing surplus or reserve issuing countries to adjust." 1

Similarly, a former World Bank president, Robert Zoelick in a speech in 2008, call for an urgent need for a 'new multilateral new global economy'; arguing that the " $G 7$ is not working, and it is an outdated mode of viewing the world", while the former French president, Nicolas Sarkozy said "we must rethink the financial system from the scratch as at Bretton Woods" (cited in Karczmarczyk, 2010, p.61).

Notwithstanding the weakness of the current international monetary system (see Bordo, 1993, 2017) and the periodic call for reforms, attempt to initiate discussion on any reform agenda has been thwarted by the privilege countries who are the beneficiaries of the status quo. While the French use to resent the U.S. dollar dominant position as an international reserve currency in the $1960 \mathrm{~s}$, but with launch of the euro and with its increasing share of international reserve currency, the call for reform has largely come from developing countries, notably China. And with the renminbi joining the IMF SDRs in 2016, prospects for reforming the current international monetary system in the foreseeable future seems remote as Bordo (2017) warned.

\subsection{Inflation}

Since the classical gold standard era, price stability remain one of the policy objectives of monetary authorities. To achieve this objective, monetary authorities are mindful that the idea does not necessarily mean that all prices are stable or fixed. In this respect, focus is on maintaining a steady relative stability but not absolute stability is the overarching goal. In terms of definition of price stability, there are two school of thought: some authors prefer to use inflation expectation, while other use quantity terms to explain it. For Bernanke (2003), price stability is both an end in itself and means for monetary policy, in that it contributes to economic growth and to macroeconomic stability. Thus, price stability is attained when a national currency or anchor can conserve its value through time or the erosion rate for purchasing power is very low. Throughout recent history, Bordo (1993, 2017) aver that expansionary monetary policies results inflation and loss of value of an anchor and eroding confidence in the ability of monetary authorities to maintain price stability. For instance, in the 1970s the Federal Reserve's inflationary policy led to a shift out of dollar holding in the rest of the world and culminated in a speculative attack on the dollar in 1978, however, the Fed has to pursue deflationary policies in order to restore confidence in the U.S. dollar as a credible international reserve currency (Eichengreen, 2010). The source of inflationary pressures are varied, internal and external. For most developing countries, inflation does not result solely from domestic economic activities but also depends on exchange rate variation under existing floating exchange rate regime, for example, Ahiabor (2013) found a positive relationship exist between exchange rate and inflation in Ghana.

\subsection{Dollarization}

One persistent outcome of the Bretton Woods system is what Andrew and Eduardo (2001, p.2) refer to a dollarization, "a shorthand for the use of any foreign currency by another country." Dollarization may be categorised into two forms: full or official dollarization and informal dollarization with its sub-themes - currency substitution and financial dollarization or assets substitution (see Andrew and Eduardo, 2001; Bannister et al., 2018). With the end of Bretton Woods regime's fixed exchange rates, nearly five decades ago, one re-ccurring theme and one that has occupy the attention of monetary authorities in transitional and developing economies is how to find a balance between growing their economies while simultaneously ensuring price stability in an international monetary system in which some few privilege countries are grantee control over their exchange rate while majority are subjected to free floating exchange rates. In this context, in most developing and transitional economies market mechanism in form of semi-official dollarization has been adopted allowing residents hold foreign currency and foreign currency-denominated deposit at domestic banks alongside local currencies, a phenomenon Brunnermeier et al (2019) refer as two anchors within these monetary system.

Empirical studies on financial dollarization measured as the share of foreign currency deposit/credit in total deposits/credit, shows that financial dollarization remains a common and persistent phenomenon with mixed result. On one hand, studies on the negative effects of partial dollarization; including weaker monetary policy transmission, currency mismatches, risks of financial stability (Tweneboah, 2016; Bannister et al., 2018; Eichengreen, 2001; Gulde et al., 2004), Yet some authors have also reported results raising the possibility that financial dollarization may be providing financial solutions to economic agents in less-than-optimal policy environments, and might support greater financial development (see Hausmann, 1999; De Nicolo et al., 2005,

\footnotetext{
${ }^{1}$ Mateosy y Lago et al., cited in Chatham House 2012, in the Introduction
} 
Levy Yeyati, 2006). Furthermore, other studies on de-dollarization give credence to the importance of credible macroeconomic stabilization policies to lower inflation and stabilise the exchange rate as key variables in the successful de-dollarization strategies in Europe and Latin America (Catao and Terrones, 2016).

\subsection{Digital economy, digital currency and "digital dollarization"}

Digitalisation has enhance efficiency in social and economic activities as well as the quality of lives in societies around the world through the production and delivery of goods and services with new business models. For instance, from ordering a cab, buying a product to making payment, technology is redefining economic and social relationship in unprecedented ways. This phenomenon has led to the emergency of the digital economy with new digital business models in cloud computing, digital platforms, and digital services. The concept of digital economy ${ }^{1}$ has varied definitions. The European Commission define digital economy as an economy based on digital technologies (European Commission, 2013). Bukht and Heeks (2017, p.17) define digital economy as "that part of economic output derived solely or primarily from digital technologies with a business model based on digital goods and services." In other words, the digital economy consist of the digital sectors plus emerging digital and platform services, and it is estimated to account for five percent of global gross domestic product and three percent of global employment. (UNCTAD, 2019)

In the area of finance, digitalization and innovation is disrupting and impacting on the nature, forms as well as mode of delivering financial products and services due to the growth of electronic, digital payments and the emergency of digital currency which Brunnermeier et al. (2019) aver has the potential for re-organization of financial services around a new 'payment-centric model' rather than the 'traditional bank-centric financial services delivery, this concerns has recently been alluded to by the head of BIS Technology Hub, Benoit Coeure $^{2}$. He said:

"Banks are worried about the implications of CBDCs for customer deposits. Central banks are mindful of these concerns and are working on answers. They see banks as part of the future CBDC systems. But make no mistake: global stablecoins, DeFi platforms and big tech firms will challenge banks' model regardless. We urgently need to ask ourselves these kinds of questions about the future. This is the far horizon for financial system but we are approaching it ever faster. Central banks need to know where they want to go as they embark on their CBDC journey"

The digital economy with its attendance connectedness which links usersship to a particular network which surpasses the boundaries of national economies might pose a challenge to not only governments around the world but more importantly the current international monetary system as digital currency areas (DCAs), redefine the ways in which payments are carried out, could reshape the nature of currency competition, the architecture of the international monetary system, and the role of government-issued public money. (Brunnermeier et al. 2019, p.2) Yet it appear central banks have been proceeding with caution but with global stablecoins now a reality, digital currency 'will do to finance what the internet did to communication, the future is already here.' According to Benoit Coeure (2021), the head of BIS Innovation Hub:

"the time has passed for central banks to get going. We should roll up our sleeves and accelerate our work on the netty-gritty of CBDC design. CBDCs will take years to be rolled out, while stablecoins and cryptoassets are already here."

Digital dollarization refer to citizens of a country using an economic, and/ or social platform with a platform native currency denominated in another country's digital currency (e.g. U.S. dollar) or an independent platform native currency such as the defunct Facebook Libra project. Brunnermeier et al (2019) define digital dollarization the phenomenon which the national currency is supplanted by a digital platform's currency rather than another developed country's currency.

\section{Digital currency ecosystem: taxonomy}

Digital currency is a fluent term, more described than defined. To date, there is no commonly accepted definition of digital currency, however, the term is generally used interchangeably with 'cryptocurrencies', 'virtual', and digital assets. This paper use digital currency, digital assets, and crypto-assets interchangeably and provide a broader definition to include private issuance of crypto-commodities, crypto-derivatives, wallet custodians, stablecoins and digital currency areas as well as state-backed digital representation of a fiat currency, referred to as CBDCs. Digital currency broadly refers to "programmable money created by developer(s), issued by private or public entity and accepted among members of a digital platform, run on blockchain and DLT or non-DLT (network protocol or smart contract); serves as a medium of exchange and unit of account." (Nantogmah et al., 2021, p.24) Central bank digital currencies on the other hand refer to a digital representation of a sovereign state

\footnotetext{
${ }^{1}$ The concept of "digital economy" was coined by Dan Tapscott, a business consultant in 1995. Since its inception, attempt to provide a clear standard definition has remained elusive.

${ }^{2}$ Benoit Coeure (2021) "Central bank digital currency: the future starts today", https://www.bis.org/speeches/sp210910.htm (accessed September 11, 2021)
} 
fiat currency. However, some scholars described mobile money and electronic money as earlier versions of digital currency (e.g., Foster et al., 2021). Figure 1 below provides a conceptual map of the digital currency ecosystem in terms of design (digital-commodity, crypto derivative, stablecoins and CBDCs), technology (decentralised ledger technology-DLT-based or non-DLT-based) and institutions (public and private), while the underlying characteristics are summarised in Table 2.

Figure 1: Taxonomy of digital currency

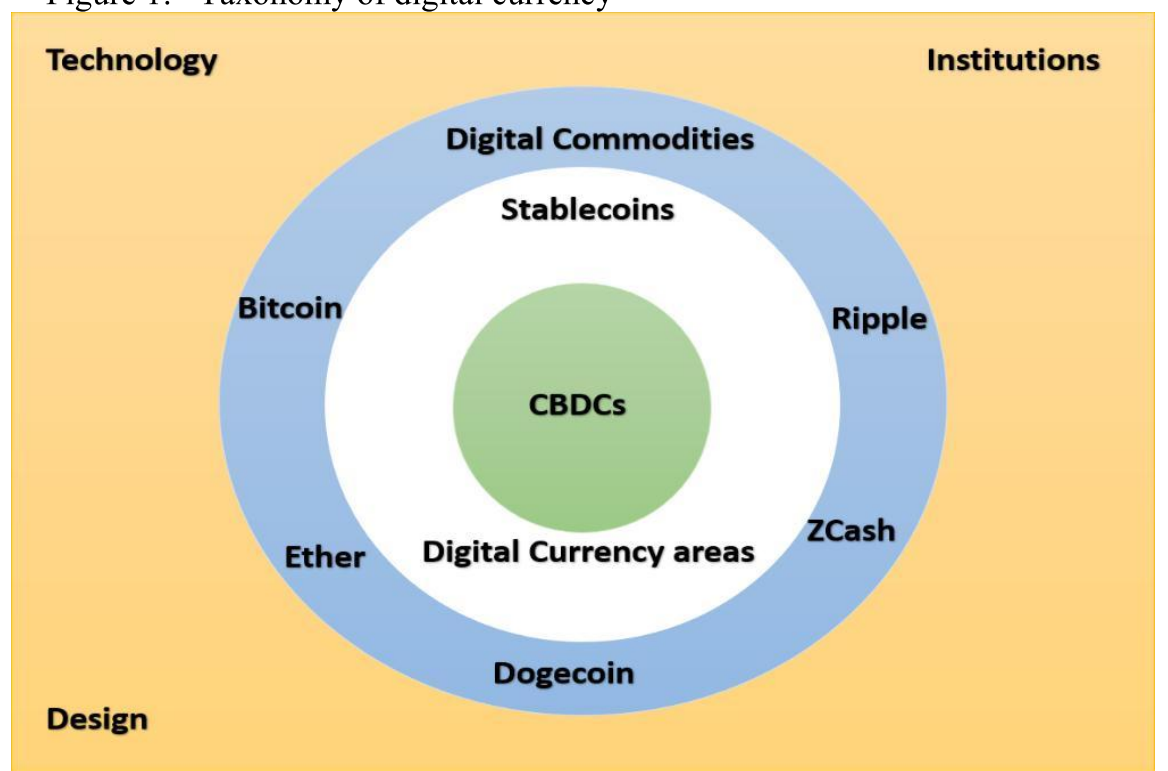

Source: Nantogmah et al., 2021, p.7

Stablecoins are digital currencies that have their market value pegged to another asset (basket of assets) or algorithmically managed and are regarded as a novel solution to the inherent crypto volatility: price stability is in-built directly into the assets. Broadly, there are four primary types of stablecoins, categorised by their underlying collateral structure: fiat-backed, crypto-backed, commodity-backed and algorithmic. Algorithmic stablecoins also referred to as Global Stablecoins (GSC) or Digital Currency Areas (DCAs) use specialised algorithms and smart contract to manage the stability of the platform native currency (Brunnermeier et al., 2019, Foster et al., 2021).

Within the digital currency ecosystem, the emergence of algorithmic stablecoin or global stablecoins has raised concerns among central bankers and global financial system governance institutions. For instance, G7 Working Group on stablecoins concluded that global stablecoin could have adverse effects both nationally and internationally on monetary sovereignty and financial stability as well as countries' efforts to combat money laundering, terrorist financing and tax avoidance. ${ }^{1}$ Facebook's proposed launch of the now defunct Libra saw pushback from regulators in the United States and Europe leading the charge. Brunnermeier et al. (2019, p.2) aver that the international character of these digital currencies will make both emerging and advanced economies vulnerable to "digital dollarization," Nonetheless, the pushback against the defunct Libra, may have nothing to do with monetary policy and financial stability concerns but more to do with the potential for such a global stablecoin to weaken the international dominance of the US dollar and the euro. This view has been given credence with the re-branding of the defunct Libra as Diem, which only US\$-backed stablecoins (Foster et al., 2021). Similarly, the U.S. President's Working Group on Financial Market recommended that "stablecoins arrangements, should be designed and operated in a responsible manner that effectively manages risk and maintains the continued stability of the U.S. domestic and international financial and monetary systems." 2

However, for most least developed countries and emerging economies; including countries in Africa, stablecoins, be it asset-backed or algorithmic, will have the same effect of 'digital dollarization and macroeconomic instability: "In countries with significant inflation and instable national fiat currencies, the issuance of central bank digital currencies may not be a solution to protecting their economies from "digital dollarization". It must be emphasized that a weak and volatile national currency, when digitalized might magnify its volatility and impact its function as store of value and medium of exchange" (Nantogmah et al. 2021, p.13)

\footnotetext{
${ }^{1}$ G7, International Monetary Fund (IMF), and The Committee on Payments and Monetary Infrastructures (CPMI), “'investigating the impact of global stablecoins', IMF, 2020, https://www.bis.org/cpmi/publ/d187.htm

${ }^{2}$ US Treasury Department (2020) President's Working Group on Financial Markets- Statement on Key Regulatory and Supervisory Issues Relevant to Certain Stablecoins, https://home.treasury.gov/system/files/136/PWG-Stablecoin-Statement-12-23-2020-CLEAN.pdf (accessed May 15, 2021)
} 


\section{Central Bank Digital Currencies (CBDCs) landscape: design and technology options}

The emergence and fast adoption of stablecoins in the digital currency ecosystem has ignited the calls for the issuance of central bank digital currencies (CBDCs). As a result, central banks are crumbling to respond to the rapidly changing payment landscape with the fear that stablecoins has the potential to be used beyond their initial role as payment instruments but as store of value as well. While some scholars warn that the emergence of stablecoins such as the defunct Facebook's Libra has the tendency to undermine public functions of central banks in respect of their authority as the sole issuer of legal tender, monetary policy and financial stability (see Brunnermeier et al., 2019), other scholars argue that the current cryptoccurency use is limited to a small proportion of economic agents and does not yet pose a threat in Africa (IFWG, 2019).

Notwithstanding this, the number of central banks engaged in CBDCs continues to grow. For instance, a recent survey carried out by BIS in January 2020, revealed that sixty-six (66) central banks representing 90 percent of global output, accounting for 80 percent of the respondents are currently (or will soon be) working on CBDC, up from 65 percent in 2017. Most central banks (around 50 percent) are focusing on both general purpose (retail) and wholesale CBDCs as well as platform-based model, 40 percent of the respondents said they have advanced from conceptual research to experiments or proof-of-concept and only 10 percent have run pilot project so far (BIS, 2020). In Africa, public information suggests that nine (9) central banks are at research and pilot stages in the development of CBDCs. Table 3 provides a summary of design and technology options, intended coverage (International or domestic) as well as stages in the development of CBDCs.

As a result of digitalisation, the barriers defining tranditional currency areas (Brunnermeier et al., 2019) has become blurred ushering fundemetal changes in the nature of social, economic and information interconnectedness, and payment systems. Digital users now clutch money on their mobile phones and transfer wealth across peer-to-peer networks to conuterpaties anywhere in the world. Central bank digital currencies are being considered in an environment where digital assets, a highly mobile currency can be transferred between people, with no financial intermediation required globally. Under these circumstances, design and technology choices need to ensure efficiency of the payment system and financial stability but more importantly ensure the stability of currency value for cross border payment and settlement.

CBDCs are a form of digital money, denominated in the national unit of account, which is a direct liability of central banks. CBDCs can be designed for use either among financial intermediaries only (i.e., Wholesale CBDCs), or by the wider economy (i.e., retail CBDCs) as well as platform-based CBDCs like the Chinese DCEP. Other design options include token-based or account-based or hybrid (tiering of account and token-based). While it is not within the scope of the paper to discuss the merits and demerits of various design and technology options being pursued by central banks around the world, it is important to synthesise the broader drivers for CBDCs: efficiency and stability of the payment and financial systems as well as serve as a stable alternative for crossborder payment and settlement in the digital economy.

A survey of twenty-five (25) developed and emerging economies researching or piloting CBDCs by Billotta and Botti (2021, pp. 31-35) revealed that majority (64 per cent) are involved in the issuance of national CBDCs, while most developed economies including IMF Special Drawing Rights reserve currencies (US dollar. Euro and the pound) are considering the possible issuance of CBDCs for domestic and international accessibility, and this may lead to what Brunnermeier et al., (2019) refer to as digital currencies areas. Similarly, Nantogmah et al. (2021 p.19) envisage the emergence of state-backed digital currency areas for the digital-dollar, e-euro, digital yen, e-pound, and the e-CNY based on current trends.

To date, discussion of the issuance of CBDCs has been led by the Bank for International Settlement (BIS) and largely influence by thinking of advance economies as the focus has been on how to design national CBDC within the context of the current international monetary architecture whose inadequacies has been amply documented (see Bordo 1993, 2017; Chatham House, 2012, Karczmarczyk, 2010). Yet the current international monetary system designed for the 20th century may not be fit for purpose for the digital economy. Indeed, for public good, central banks must retain their ability to deliver price stability and financial stability, yet a new international monetary system may be inevitable and should be part of the design discussion of CBDCs, in accordance with democratic principles (see Coeure, 2021).

\section{CBDCs in Africa: why CBDCs could be a 'disaster' for the continent}

From table 3, CBDCs 'are here to stay and Africa must wake to this 'new norm' and begin to speak with one voice in an emerging new international monetary architecture which needs to be negotiated within the broader context of the digital economy. However, discussions on CBDCs in developed economies and among global financial governance institutions appear to be developed countries-centric and thereby painting an erroneous impression that CBDCs are the only solution to the increasing spread and adoption of digital currencies in general, and global stablecoins in particular in developing and emerging economies. First, under existing international monetary architecture for the issuance of CBDCs, and the prevailing economic conditions of high inflation and national currency volatility with inherent dollarization and digital dollarization, no economy in 
Africa can stand the power of big tech and foreign sovereign digital currencies (see Bilotta and Botti, 2021, Foster et al., 2021, Nantogmah et al, 2021, Brunnermeier et al., 2019). Without addressing these issues of national currency instability and inflation, African countries risk issuing volatile and instable individual CBDCs only to be replaced by digital dollarization as was pointed out in Facebook's White paper on the defunct Libra coin: "for regions where there is no stable currency the libra conin could fill this void and act as a "replacement" to increase financial inclusion." (Nantogmah et al., 2021, p.18)

Second, research on digital currency among central banks in Africa, has arguably been focused on design and technology options for the issuance of CBDCs to the neglect of impact of digital currency on national and regional economy. For instance, a South African government Fintech Working Group noted that the cryptoassets market does not currently pose a threat to financial stability, although the report highlights the $3200 \%$ market capitalization growth rate in 2017 as a reason for regulators to keep an eye on developments in the market (I FWG, 2019).

Finally, regulatory inaction, across the African continent, governments and central banks posture on digital currency has been largely "laissez faire" and restrictive in North African countries (Nantogmah et al., 2021, pp.9-10). But Masela (2021, p.142) reports that, in the SADC region, while countries are reviewing or considering reviewing their posture on crypto-assets, authorities have generally warned the public about possible exposure in using crypto-assets but countries have currently chosen not to regulate crypto-assets. However, the author noted that a recent IFWG position paper might lead to some form of regulation of crypto-assets. Yet without regulatory positions in relation to the crypto industry, the launch of CBDCs in Africa might lead African countries to adopt regulatory framework designed for developed economies which may be inimical to the interest of Africa and its citizens. Furthermore, Foster et al., (2021) presents potential risks and macroeconomic implications of digital currency both nationally and internationally including those related to the fragmented regulatory approaches as well as the emerging technology and governance structures that do not fall within traditional regulatory oversight.

\section{Alternatives to CBDCs in Africa: Continental Approach -'stairway to heaven'}

"The current international monetary system and global financial system was designed for the $20^{\text {th }}$ century and might not be fit for purpose in the digital economy as its architecture is bank-centric in a new payment-centric $21^{\text {st }}$ century digital era. A new international monetary system to meet the needs of the digital era is inevitable and to be taken seriously in this uncharted waters, Africa must establish a single digital currency or a digital currency payment platform with continental and international interlinkages."

The idea that Africa's prosperity and economic emancipation from neo-colonialism is interlinked with the thesis-"Africa Must Unite' authored by Kwame Nkrumah, the African of the Millennium and widely celebrated as a champion of Pan Africanism and regional integration who as early as 1958 convene the All African People Conference (AAPC) to advance the vision of United States of Africa. While the potential benefits of a single currency for Africa have been widely acknowledge and has never been in contention, attempt to achieve regional economic integration has to date proved to be a mirage. But regarding the benefit of a single common currency for the continent, Nkrumah said:

"..... While a common currency would eliminate the difficulties of exchanges as well as the illegitimate dealings which at present rob us of part of our wealth. A common currency, free of links with outside currency zones, would enable us reserve the foreign exchange made from our export trade for essential imports."

Kwame Nkrumah, 1963, p.179

In pursuance of regional integration agenda, African leaders recently launched two most important initiative- the African Continental Free Trade Area (AfCFTA) and the Pan African Payment and Settlement System (PAPSS). According to Cointelegraphnews, Ghana's Vice President Dr. Mahamudu Bawumia recently said that African governments need to embrace digital currencies to facilitate trade throughout the continent and argued that trade between African countries demands a "single central payment" system. ${ }^{1}$ Similarly, Nantogmah et al., (2021, p.17) suggest the establishment of continental digital currency payment platform with a native currency (e.g. Eco):

"The process of digitalisation cannot be reversed, on the contrary, has gained momentum and a regional digital currency could take Africa closer to the dream of an Africa Monetary Union envisaged six decades ago. Adopting a common digital currency would guarantee that no change in third-country exchange rates would disturb the trading relationship among African countries themselves."

Alternatively, Foster et al. (2021) aver that with the proliferation of digital currencies projects undertaken ${ }^{1}$ Cointelegrahmnews, Bank of Ghana to Pilot CBDC with German Securities Printing Firm-G+D, https://cointelegraph.com/news/bank-of-
ghana-to-pilot-cbdc-with-german-securities-printing-firm-g-d, (accessed August 15, 2021) 
by sovereign states and regions like EU. Similar initiatives to create both an Anglophone West African Bloc currency by ECOWAS (to be known as 'Eco') and as East African bloc currency by EAC are under consideration. For the authors, this provides a foundation for the potential emergence of bloc cryptocurrencies across Africa in line with existing regional blocs. Yet the use of regional economic communities as building blocs, refer to as 'gradualist approach' has proven to be ineffective after five decades of practice and is unlikely to be an effective tool for regional integration in $21^{\text {st }}$ century and the digital economy.

\section{Conclusion and recommendations}

Digital currency is here to stay as advance economies notably G7 countries have moved with greater speed to provide legal and policy framework for regulating the digital currency industry, but Africa is not at table yet as global rules for the digital economy are been discuss with a view to transposes the current international monetary system to the digital economy in order to preserve the privileged position for advance countries, while continuing to subjugate developing economies to digital dollarization. This is manifested in the backlash to the defunct Facebook Libra project and the general dislike of global stablecoins which makes both emerging and advance economies susceptible to digital dollarization. Yet as central banks crumble to 'keep their feet's in a moving stream', it appears they are shutting 'the stable door after the horse has bolted.' As Coeure (2021) admits: "the financial system is shifting under our feet"; but "CBDCs will take years to be rolled out, while stablecoins and cryptoassets are already here." But what is clear to date, is that discussions on technology and design options for CBDCs are underway in many advanced economies, including China which is the first to launch a Digital Currency and Electronic Payment Platform with its native coin -yuan. However, with currency substitution inevitable in the digital economy, it might be counterproductive to simply reform or update an 'ancient and worn-out international monetary system, the time to create a truly new international monetary system that is fair and just for a new global economy cannot be stress enough.

Under these circumstances, African central banks and governments must embark on the CBDCs journey with caution. In the absence of national and/or regional crypto-assets regulatory framework, CBDCs in Africa without addressing persistent weakness of local currencies, unfair international monetary system, high inflation and economic instability could be a disaster for the continent. But the good news is that digital currency technology also provides Africa with a unique opportunity to develop and manage a single regional digital currency, and African countries must decide whether they want to cede their sovereign power to an independent central bank with single digital currency to manage under their control or cede their economic and financial destiny to unaccountable foreign BigFintech and/or foreign sovereign CBDCs in the form of digital dollarization.

\section{Recommendations}

Regional currency Area. The digital economy would be organised around the centrality of payments and digital currency areas- private and public. CBDCs in Africa, might be susceptible to digital dollarization but there is an opportunity to transform the proposed Pan African Payment and Settlement System (PAPSS) into African Digital Currency Payment Platform with a native design taking into account available home grown technology and the interest African citizens as such a regional digital currency area/platform has the potential boosts intra-African trade and regional integration agenda. However, governments and regulators in Africa need to forge publicprivate partnerships to discuss digital currency technology and design options before proceeding to develop the core features of the CBDC instrument or a regional digital currency area.

International Monetary system. The digital economy and digital currencies has ushered the world of finance into uncharted waters, reform of old systems and institutions, to operate in this dynamic environment may be counterproductive and the need for a new international monetary system is inevitable. Africa must not approach the digital era with multi-voices and currencies but with one voice in order to be able to influence ensuing negations to establish a new international monetary architecture which is fair and anchored on democratic principles.

Regulation. Regulation of digital assets in Africa has not received high priority with the exception of South Africa where the issue is under consideration. But without a regulatory framework, the continent might not realise benefits associated with digital currency. To date, with the exception of the European Union which has adopted a regional approach to digital assets regulation, crypto-assets regulation has largely remained country focused with less regulatory attention on cross-border effects. To address the current regulatory arbitrage, Africa should pursue a regional approach with a common regulatory framework for the digital currency ecosystem within the context of the AfCFTA.

Public-Private Partnerships. A well-designed regional digital currency or CBDC involves a complex undertaking in a fluid technology environment which requires hands-on oversight role for African central banks. Therefore, public-private partnerships to develop the core features of the CBDC instrument and its underlying system are inevitable in facilitating open finance architecture anchored on continuous innovation while encouraging competition. 
Research capacity. To ensure Africa build core competencies in digital economy research, core and productive digital skills required to effectively manage the digital currency ecosystem, the continent need to establish Digital Currency Working Group.

\section{References}

Ahiabor Godson (2013) "The Effects of Monetary Policy on Inflation in Ghana," Developing Country Studies, Vol.3, No. 12

Balino, T., Bennett \& E. Borensztein, (1999) "Monetary Policy in Dollarized Economies", IMF Occasional Paper No. 171. International Monetary Fund

Bank of England (2020) Discussion Paper: Central Bank Digital Currency Opportunities, challenges and design, March 2020

Bank for International Settlement (2021) III. CBDCs: an opportunity for the monetary system, BIS Annual Economic Report, https://www.bis.org/publ/arpdf/ar2021e3.pdf

BIS, G7, International Monetary Fund (IMF), and The Committee on Payments and Monetary Infrastructures (CPMI), "'investigating the impact of global stablecoins', IMF, 2020, https://www.bis.org/cpmi/publ/d187.htm (July, 2021)

Bannister Geoffrey, Gardberg Malin, \& Turunen, Jarkko (2018) Dollarization and Financial Development. IMF Working Paper, WP/18/200,

Bernanke, B (2003) Constrained Discretion and Monetary Policy. New York, NY: Remarks before the Money Marketeers of New York University, https://www.federalreserve.gov/boarddocs/speeches/2003/20030203/default.htm (accessed 01/09/2021)

Benoit Coeure (2021) "Central bank digital currency: the future starts today", https://www.bis.org/speeches/sp210910.htm (accessed September 11, 2021)

Bilotta Nicola and Botti Fabrizio (2021) "The (Near) Future of Central Bank Digital Currencies: Risks and Opportunities for the Global Economy and Society”, Peter Lang AG, International Academic Publishers, Bern, Italy

Bordo Michael D (2017) The Operation and Demise of the Bretton Woods System; 1958 to 1971, Economics Working Paper, National Bureau Research, https://www.hoover.org/sites/default/files/research/docs/16116-bordo.pdf

Bordo Michael D (1993) the Bretton Woods International System: A Historical Overview; In Bordo Michael D. and Eichengreen Barry (1993) Retrospective on the Bretton Woods System: Lessons for International Monetary reforms, University of Chicago Press

Brunnermeier Markus K., Harold James, Jean-Pierre Laudau (2019) “The Digitalization of Money", Working Paper 26300, http://www.nber.org/papers/w26300,( accessed on 23/03/2021 )

Bukht Rumana and Heeks Richard (2017) "Defining, conceptualising and measuring the digital economy", GDI Development Informatics Working Papers, no. 68,

Chatham House (2012) Gold and the International Monetary System: A report by the Chatham House Gold Taskforce,

file://C:/Users/user/Desktop/2018_2021Academic\%20Year/2020_2021_Academic\%20Year/Papers/Paper $\% 20$ undate/Gold\%20standards\%20and\%20monetary\%20policy anchor.pdf (accessed on August 25, 2021)

De Nicolo, P. Honohan \& A. Ize (2005) "Dollarization of Bank Deposits: Causes and Consequences", Journal of Banking and Finance 29, pp. 1697 - 1727

Eichenhreen, Barry (2021) Will central bank digital currencies dethrone the dollar

https://www.theguardian.com/business/2021/aug/10/will-central-bank-digital-currencies-dethrone-the-dollar (access on August 14, 2021)

Eichengreen, Barry (2001) “what problems can dollarization solve?” Journal of Policy Modelling, 23, issue 3, 267-277

Gulde, Anne Marie; David S. Hoelscher; Iain Ize; Dewitt D. Marston \& Gianni De Nicolo (2004) "Financial Stability in Dollarized Economies," IMF Occasional Papers 230, International Monetary Fund.

Hausmann, Ricardo (1999) "Should there be five currencies or one hundred and five?" Foreign Policy, 116, 6579

$\begin{array}{llll}\text { Intergovernmental } & \text { Fintech } & \text { Working } & \text { Group }\end{array}$ https://www.fic.gov.za/Documents/IFWG_2019WorkshopsReport v1.0.pdf

Karczmarczyk, Catherine Ardra (2010) History of the international monetary system and its potential reformation, Chancellor's Honors Program Project, https://trace.teninessee.edu/utk_chanhonoproj/1341 (accessed August 20, 2021)

Levy Yeyati Eduardo (2006) "Financial Dollarization: Evaluating the Consequences" Economic Policy, Vol. 21, No. 45 , pp. 61-118

Intergovernmental

Fintech

Working

Group

(IFWG), 
https://www.fic.gov.za/Documents/IFWG_2019WorkshopsReport_v1.0.pdf

Masela, P.M.T. (2021) Digital Currency Initiatives on the African Continent, In Bilotta Nicola and Botti Fabrizio (2021) The (Near) Future of Central Bank Digital Currencies: Risks and Opportunities for the Global Economy and Society, Peter Lang AG, International Academic Publishers, Bern, Italy

Nantogmah D, Sampson V. E. and Odoom A. A. (2021) "Political economy of digital currency in Africa: design, technology and regulation", BTU Discussion Paper https://www.academia.edu/51783226/Political_Eeconomy_of_Digital_Currency_in_Africa_design_technol ogy_and_regulations_BTU_Discussion_Paper_No_3_August_2021

Nkrumah Kwame (1963) Africa Must Unite, Special Edition (Reprint), Kwame Nkrumah Pan African Centre, Accra

Tweneboah, George; John Garchie Gatsi \& Asamoah Micchael Effah (2019) "Financial development and dollarization in Ghana: an empirical investigation," cogent economics and finance, 7:1

UNCTAD (2019) Digital Economy Report 2019: Value Creation and Capture-Implications for Developing Countries, United Nations publication, Sales No. E.19.II.D17, New York and Geneva

United States Treasury Department, President's Working Group on Financial Markets- Statement on Key Regulatory and Supervisory Issues Relevant to Certain Stablecoins, https://home.treasury.gov/system/files/136/PWG-Stablecoin-Statement-12-23-2020-CLEAN.pdf (accessed May 15, 2021)

Table 1: Top six cryptocurrencies by market capitalisation, September, 2021

\begin{tabular}{ccccccc} 
No. & Name & Symbol & Market capitalisation & Unit price & Circulating supply & Volume $(24 \mathrm{~h})$ \\
\hline 1 & Bitcoin & BTC & $\$ 835,094,922,267$ & $\$ 44,258.50$ & $18,676,412$ & $\$ 39,936,046,052$ \\
2 & Ethereum & ETH & $\$ 376,383,804,802$ & $\$ 3,194.33$ & $117,507,541$ & $\$ 22,099,796,298$ \\
3 & Cardano & ADA & $\$ 77,363,423,209$ & $\$ 2.40$ & $32,038,100,544$ & $\$ 7,692,460,455$ \\
4 & Tether & USDT & $\$ 68,282,625,577$ & $\$ 1.00$ & $68,260,615,736$ & $\$ 99,632,543,462$ \\
3 & Binance & BNB & $\$ 66,668,404,303$ & $\$ 394.13$ & $168,137,036$ & $\$ 2,300,106,966$ \\
6 & Ripple & XRP & $\$ 48,884,264,412$ & $\$ 1.05$ & $46,585,282,244$ & $\$ 21,570,153,938$
\end{tabular}

Source: https://coinmarketcap.com/, date of access: 13 September 2021

\begin{tabular}{|c|c|c|}
\hline Digital Asset & Features & Examples \\
\hline Digital-commodities & $\begin{array}{l}\text { Private Issuer } \\
\text { DLT-based or non-DLT based } \\
\text { Ceilings on number of units/growth rate } \\
\text { Price volatility and most risky } \\
\text { Payment systems }\end{array}$ & $\begin{array}{l}\text { Bitcoin, Ether, ripple, litecoin. } \\
\text { dogecoin, stellar,peercoin etc }\end{array}$ \\
\hline $\begin{array}{l}\text { Asset-backed- } \\
\text { Stablecoins } \\
\text { (crypto exchanges) }\end{array}$ & $\begin{array}{l}\text { Private Issuer } \\
\text { Payment systems } \\
\text { Trading platform } \\
\text { Act as Custodians } \\
\text { Asset-backed }(1: 1) \\
\text { Regulation: Depends on Juridiction }\end{array}$ & $\begin{array}{l}\text { Binance, Cardano, Tether, XRI } \\
\text { Dogo, USD Coin, Solana, } \\
\text { Polkadot etc }\end{array}$ \\
\hline $\begin{array}{l}\text { Algorithmic } \\
\text { (Stablcoins-Multi- } \\
\text { currency) }\end{array}$ & $\begin{array}{l}\text { Private Issuer } \\
\text { Algorithmically managed (smart contract) } \\
\text { independent currency unit } \\
\text { Payment systems } \\
\text { Trading platform } \\
\text { Non-DLT based }\end{array}$ & Defunct Libra, Libie \\
\hline CBDCs & $\begin{array}{l}\text { Public Issuer } \\
\text { State-backed, highly secured } \\
\text { DLT-based or non-DLT based } \\
\text { Retail/wholesale/platform } \\
\text { payment system/multi-purpose }\end{array}$ & $\begin{array}{l}\text { Digital-dollar, e-euro, e-cedi } \\
\text { DCEP/Yuan, e-pound, e-dinar } \\
\text { DXCD, e-krone, e-krona, } \\
\text { e-dollar etc }\end{array}$ \\
\hline $\begin{array}{l}\text { Institutional } \\
\text { Architecture }\end{array}$ & $\begin{array}{l}\text { Centralised or decentralised } \\
\text { Wallet Providers } \\
\text { Crypto Exchanges (pysical presence or } \mathrm{p} \\
\text { Merchants/payment facilitators }\end{array}$ & rely online) \\
\hline
\end{tabular}

Source: Author 
Table 3: Features of Central Bank Digital Currencies (CBDCs) Proposals

\section{Design Choices}

\section{Country}

United States

United Kingdom

European Union

Canada

Australia

Japan

Russia

Switzerland

Sweden

Tunisia

Eastern Caribbean

China

South Africa

Ghana

Nigeria

Kenya

Rwanda

Morocco

Egypt

Mauritius

Eswatin

Brazil

Malaysia

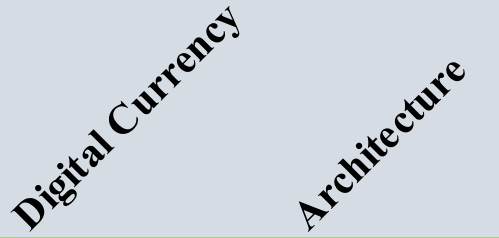

digtal-dollar

e-pound

e-euro

e-dollar

e-AUD

digital Yen

e-rouble

e-franc

e-krona

e-dinnar

DXCD

e-CNY

e-rand

e-cedi

CBDC

CBDC

CBDC

CBDC

CBDC

CBDC

e-lilangeni

digital real

e-ringgit

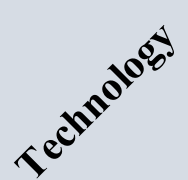

$\mathrm{U}$

$\mathrm{H}$ or I

$\mathrm{H}$ or I

$\mathrm{H}$ or I

$\mathrm{U}$

U

U

U

$\mathrm{H}$ or I

U

U

$\mathrm{H}$ or I

U

$\mathrm{U}$

$\mathrm{U}$

U

$\mathrm{U}$

U

U

U

U

$\mathrm{H}$ or I

U

\section{U}

U

D

D\&C

$\mathrm{U}$

U

U

$\mathrm{U}$

D

U

D

D\&C

U

$\mathrm{U}$

U

U

U

U

U

U

U

D

U

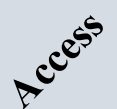

U

U

$\mathrm{A} / \mathrm{T}$

$\mathrm{A} / \mathrm{T}$

U

U

U

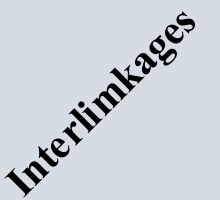

$\mathrm{U}$

U Research

Research

I Research

N Pilot

U Research

\section{Notes:}

Architecture: $\mathrm{D}=$ direct, $\mathrm{H}$ or I =hybrid ot Intermediated, $\mathrm{U}=$ Unspecified or multiple options Technology: $C=$ conventional, $D=D L T$. $U=$ Unspecified or multiple options under consideration Access: $A=$ account-based, $A / T=$ Tiering of account and token-based, $T=$ token-based, $U=$ options Interlinkage: $\mathrm{I}$ = international, $\mathrm{N}=$ national, $\mathrm{U}=$ =unspecified ormultiple options under consideration Source: Bilotta and Botti, 2021, CBDCtracker, https://cbdctracker.org/ 